\title{
DYREKTORZY SZKÓŁ W POLSCE - WYMAGANIA, STRUKTURA, ZADANIA
}

\begin{abstract}
AвSTRACt. Madalińska-Michalak Joanna, Dyrektorzy szkót w Polsce - wymagania, struktura, zadania [Schools Principals in Poland - Requirements, Structure and Responsibilities]. Studia Edukacyjne nr 55, 2019, Poznań 2019, pp. 59-77. Adam Mickiewicz University Press. ISSN 1233-6688. DOI: $10.14746 /$ se.2019.55.4
\end{abstract}

The paper presents the findings derived from the study on school principals in Poland. The study is guided by the following research questions: What requirements are addressed to candidates for the position of a school principal? Who are school principals? How does the structure of school principals look like? What tasks does the school principal have to perform? The basis of the research study is the review of the laws in force from September 1, 2018 in the field of education and accompanying executive regulations, as well as the analysis of data available in the database of the Educational Information System and the data of the Ministry of National Education. The findings inform about educational policy and practice and at the same time contribute to further research on the socio-professional status of school principals in Poland as well as on research on working conditions and the professionalization of school principal activities.

Key words: school principal, status of school principals, requirements towards candidates for the position of school principal, structure of school principals, school principals' responsibilities

\section{Uwagi wprowadzające}

Przedmiotem prowadzonych tutaj rozważań jest dyrektor polskiej szkoły. Problematyka dotycząca dyrektora szkoły jest tak bogata, że ze względu na ograniczone ramy niniejszego artykułu byłam zmuszona do wyboru jedynie kilku kwestii spośród całej palety problemów. Omówienie tych kwestii - jak zakładam - przybliży postać dyrektora polskiej szkoły i nakreśli obszar jego obowiązków, zadań oraz wymagań, jakie są kierowane pod adresem kandydatów na stanowisko dyrektora szkoły. Przedstawione analizy oraz towarzyszące im wyniki mogą okazać się istotne dla polityki i praktyki w zakresie 
rekrutacji, rozwoju zawodowego i zatrzymywania w zawodzie przyszłych, jak też obecnie pracujących dyrektorów szkół, a jednocześnie mogą przyczynić się do dalszych badań nad statusem społeczno-zawodowym dyrektorów szkół w Polsce, a także badań nad warunkami pracy i profesjonalizacją działań dyrektora szkoły.

U podstaw prowadzonych tutaj rozważań leżą odpowiedzi na następujące pytania:

- Jakie wymagania są kierowane do kandydatów na stanowisko dyrektora szkoły?

- Kim są dyrektorzy szkół? Jak kształtuje się ich struktura?

- Jakie zadania ma do wypełnienia dyrektor szkoły?

W podjęciu odpowiedzi na pytania dotyczące wymagań, kierowanych do kandydatów na dyrektorów szkół oraz odnoszące się do zadań, jakie ma do wypełnienia dyrektor szkoły niezwykle pomocny był przegląd obowiązujących od 1 września 2018 roku ustaw z obszaru spraw edukacyjnych: Ustawa z 14 grudnia 2016 r. Prawo oświatowe, przepisy wprowadzające Ustawę z 14 grudnia 2016 r. Prawo oświatowe, Ustawa z 7 września 1991 r. o systemie oświaty, Ustawa z 27 października 2017 r. o finansowaniu zadań oświatowych, Ustawa z 26 stycznia 1982 r. Karta Nauczyciela oraz Ustawa z 15 kwietnia 2011 r. o systemie informacji oświatowej oraz towarzyszące im rozporządzenia wykonawcze, w tym Rozporządzenie Ministra Edukacji Narodowej z 11 sierpnia 2017 r. w sprawie wymagań, jakim powinna odpowiadać osoba zajmująca stanowisko dyrektora oraz inne stanowisko kierownicze w publicznym przedszkolu, publicznej szkole podstawowej, publicznej szkole ponadpodstawowej oraz publicznej placówce i Rozporządzenie Ministra Edukacji Narodowej z 25 sierpnia 2017 r. w sprawie nadzoru pedagogicznego. Natomiast, podstawą przedstawienia obrazu dyrektora szkoły w Polsce $\mathrm{w}$ ujęciu statystycznym była analiza danych dostępnych w bazie danych Systemu Informacji Oświatowej i danych Ministerstwa Edukacji Narodowej, które zostały przekazane mi przez MEN na moją prośbę.

Zastosowane metody poszukiwań badawczych miały sprzyjać postawionemu w niniejszym artykule problemowi, jakim jest obraz dyrektora szkoły w Polsce w świetle najnowszych wymogów prawa oświatowego i danych statystycznych ukazujących strukturę dyrektorów szkół w ujęciu dynamicznym. Tak postawiony problem i zastosowane metody badawcze, mimo badań prowadzonych wcześniej w tym zakresie ${ }^{1}$, stanowi, biorąc głównie pod uwagę aktualność analizowanych danych, nowe jego ujęcie.

1 A.J. Jeżowski, J. Madalińska-Michalak, Dyrektor szkoły - koncepcje i wyzwania. Między teorią a praktyka, Warszawa 2015; S. Więsław, Sytuacja i status zawodowy dyrektorów szkót i placówek oświatowych, Warszawa 2012. 


\section{Powierzenie stanowiska dyrektora szkoły - wymagania, jakie należy spełnić}

Ilekroć nasze rozważania koncentrują się wokół kwestii dotyczącej kierowania szkołą, tylekroć nasze myśli zwracają się ku dyrektorowi szkoły i roli, jaką pełni on w szkole. Odpowiedź na pytanie, kim jest i jaki jest dyrektor współczesnej szkoły w Polsce nie jest łatwa i jednoznaczna. Dyrektora szkoły (czy innej placówki edukacyjnej) trudno zdefiniować jednym zdaniem, a nawet trudno opisać w ramach kilkustronicowego artykułu. Możliwości, jakie stwarzają nie tylko podpowiedzi legislacyjne, ale także odwołania do teoretycznych koncepcji zarządzania jednostką organizacyjną systemu edukacji, jaką jest szkoła, tudzież studia porównawcze między różnymi systemami i rozwiązaniami przyjętymi na świecie powodują, że jednoznacznej, precyzyjnej podpowiedzi raczej nie należy oczekiwać. Można zatem postawić pytanie inne: kto jest/może być dyrektorem szkoły w Polsce? Tak sformułowane pytanie kieruje naszą uwagę w stronę wymogów, jakie należy spełnić, aby móc zajmować stanowisko dyrektora szkoły w Polsce.

I tak, z punktu widzenia prawa status dyrektora szkoły wyznaczają obecnie między innymi:

- Ustawa z 14 grudnia 2016 r. Prawo oświatowe,

- Ustawa z 26 stycznia 1982 r. Karta Nauczyciela,

- Rozporządzenie Ministra Edukacji Narodowej z 11 sierpnia 2017 r. w sprawie wymagań, jakim powinna odpowiadać osoba zajmująca stanowisko dyrektora oraz inne stanowisko kierownicze w publicznym przedszkolu, publicznej szkole podstawowej, publicznej szkole ponadpodstawowej oraz publicznej placówce.

Obok wskazanych przepisów prawa status ten wyznacza wiele innych ustaw i ponad sto rozporządzeń, licząc tylko akty w obszarze tak zwanego prawa oświatowego.

Zgodnie ze współcześnie obowiązującymi regulacjami prawa oświatowego,

szkołą lub placówką kieruje nauczyciel mianowany lub dyplomowany, któremu powierzono stanowisko dyrektora. Szkołą lub placówką może również kierować osoba niebędąca nauczycielem, powołana na stanowisko dyrektora przez organ prowadzący, po zasięgnięciu opinii organu sprawującego nadzór pedagogiczny² ${ }^{2}$

Uzupełnić należy, że zgodnie z ustawą, osoba niebędąca nauczycielem nie może sprawować nadzoru pedagogicznego i w takim przypadku nadzór pedagogiczny sprawuje nauczyciel zajmujący inne stanowisko kierownicze

\footnotetext{
${ }^{2}$ UPO, art. 62 ust. 1 i 2 (DzU z 2017 r. poz. 60 ze zm.).
} 
w szkole lub placówce, na przykład wicedyrektor ${ }^{3}$. Prawo oświatowe pokazuje zatem, że szkołą publiczną w Polsce kieruje osoba, której organ prowadzący powierzył stanowisko dyrektora szkoły. Powierzenie to następuje w wyniku konkursu4. Polskie prawo wymaga także, by osoba, która przyjmie stanowisko dyrektora szkoły była w zasadzie czynnym nauczycielem. Możliwe jest odstępstwo od tego wymagania, ale pod warunkiem pozytywnej opinii kuratora oświaty. I jest to zjawisko nader rzadkie.

Należy zauważyć, że minister edukacji dodatkowo doprecyzowuje wymagania stawiane kandydatom na stanowisko dyrektora szkoły. Świadczy o tym chociażby Rozporządzenie Ministra Edukacji Narodowej z 11 sierpnia 2017 r. w sprawie wymagań, jakim powinna odpowiadać osoba zajmująca stanowisko dyrektora oraz inne stanowisko kierownicze w publicznym przedszkolu, publicznej szkole podstawowej, publicznej szkole ponadpodstawowej oraz publicznej placówce, zasadniczo powtarza rozwiązanie przyjęte w poprzednim rozporządzeniu z roku 2009. Wydanie nowego rozporządzenia było konieczne z uwagi na zmiany, jakie wprowadziła Ustawa z 14.12.2016 r. Prawo oświatowe. Zgodnie z przepisami w tym Rozporządzeniu, stanowisko dyrektora publicznego przedszkola, publicznej szkoły podstawowej i publicznej szkoły ponadpodstawowej, oraz publicznej placówki może zajmować nauczyciel mianowany lub dyplomowany, który spełnia łącznie następujące wymagania: posiada wykształcenie wyższe i tytuł zawodowy magister, magister inżynier lub równorzędny, oraz przygotowanie pedagogiczne i kwalifikacje do zajmowania stanowiska nauczyciela w danym przedszkolu, szkole lub placówce; ukończył studia wyższe lub studia podyplomowe z zakresu zarządzania albo kurs kwalifikacyjny z zakresu zarządzania oświatą prowadzony zgodnie z przepisami w sprawie placówek doskonalenia nauczycieli; posiada co najmniej pięcioletni staż pracy pedagogicznej na stanowisku nauczyciela lub pięcioletni staż pracy dydaktycznej na stanowisku nauczyciela akademickiego; uzyskał co najmniej dobrą ocenę pracy (...) lub pozytywną ocenę dorobku zawodowego (...); spełnia warunki zdrowotne niezbędne do wykonywania pracy na stanowisku kierowniczym; ma pełną zdolność do czynności

\footnotetext{
${ }^{3}$ UPO, art. 62 ust. 3 (DzU z 2017 r. poz. 60 ze zm.).

${ }^{4}$ Należy podkreślić, że już w ustawie z 1 lipca 1926 r. o stosunkach służbowych nauczycieli (DzU z 1932 r. nr 104, poz. 873 ze zm.) zdecydowano, że mianowanie na stałe posady nauczycieli oraz na stanowiska dyrektorów i kierowników szkół, odbywa się na podstawie konkursu. Na każdą nowo utworzoną lub opróżnioną stałą posadę nauczyciela, czy stanowisko dyrektora i kierownika szkoły, o ile nie zostanie zajęte $\mathrm{w}$ drodze służbowej lub dyscyplinarnej, ogłasza się konkurs, w tym na dyrektorów i kierowników szkół (w terminie) do dni 30, a termin ten liczył się od dnia utworzenia lub opróżnienia stanowiska. Dopilnowano też, że przy podwyższeniu stopnia organizacyjnego szkoły powszechnej z pierwszego stopnia na stopień wyższy, lub łączenia kilku szkół stopnia pierwszego w jedną szkołę stopnia wyższego, także należy rozpisać konkurs na jej kierownika.
} 
prawnych i korzysta z pełni praw publicznych; nie był prawomocnie ukarany karą dyscyplinarną (...) oraz nie toczy się przeciwko niemu postępowanie dyscyplinarne; nie był skazany prawomocnym wyrokiem za umyślne przestępstwo lub umyślne przestępstwo skarbowe; nie toczy się przeciwko nie$\mathrm{mu}$ postępowanie o przestępstwo ścigane $\mathrm{z}$ oskarżenia publicznego; nie był karany zakazem pełnienia funkcji związanych z dysponowaniem środkami publicznymi (...). Warunków sine qua non jest więc bardzo dużo.

Należy mieć na uwadze, że wymagania względem osoby, która ma zajmować stanowisko dyrektora szkoły, nawet tak drobiazgowo określone, nie są jednak ostateczne. Prawo nie jest w stanie przewidzieć każdej sytuacji. Nie jest ono w stanie z góry rozstrzygnąć o sytuacjach losowych i zwyczajnie po ludzku zróżnicowanych. Do podejmowania spraw z tego zakresu włączone zostały sądy. I to one, często $w$ indywidualnych i jednostkowych sprawach, muszą zdecydować o danej sprawie.

\section{Obraz dyrektora szkoły - ujęcie statystyczne}

Przedstawiając obraz dyrektora szkoły w ujęciu statystycznym, należy wziąć pod uwagę także wicedyrektorów. Jest ku temu kilka powodów. Pierwszy, że stanowią sporą część kadry kierowniczej edukacji, bo we wrześniu 2014 roku było to ponad 15 tys. osób, to znaczy 35,8\% tej grupy. Drugi, że Ustawa Prawo oświatowe - umiejscawia wicedyrektora w strukturze szkoły, postanawiając między innymi, że:

- do czasu powołania na stanowisko dyrektora placówki, o której mowa w ust. 2, zgodnie z ust. 3 lub 4, właściwy minister prowadzący placówkę może powierzyć pełnienie obowiązków dyrektora placówki wicedyrektorowi albo innemu pracownikowi tej placówki (art. 63 ust. 5);

- do czasu powierzenia stanowiska dyrektora, zgodnie z ust. 10 lub 12, organ prowadzący może powierzyć pełnienie obowiązków dyrektora szkoły wicedyrektorowi, a w szkołach, w których nie ma wicedyrektora, nauczycielowi tej szkoły, jednak nie dłużej niż na 10 miesięcy (art. 63 ust. 13);

- jeżeli w szkole utworzono stanowisko wicedyrektora lub inne stanowiska kierownicze, powierzenia tych stanowisk i odwołania $\mathrm{z}$ nich dokonuje dyrektor szkoły, po zasięgnięciu opinii organu prowadzącego, rady szkoły oraz rady pedagogicznej (art. 64 ust. 1);

- $\mathrm{w}$ placówce, $\mathrm{w}$ której zgodnie z ramowym statutem może być utworzone stanowisko wicedyrektora i inne stanowiska kierownicze, powierzenia tych stanowisk i odwołania z nich dokonuje dyrektor placówki, po zasięgnięciu opinii organu prowadzącego, rady placówki oraz rady pedagogicznej (art. 65 ust. 1); 
- w przypadku nieobecności dyrektora szkoły lub placówki zastępuje go wicedyrektor, a w szkołach i placówkach, w których nie utworzono stanowiska wicedyrektora - inny nauczyciel tej szkoły lub placówki, wyznaczony przez organ prowadzący (art. 68 ust. 9);

- w szkole, która liczy co najmniej 12 oddziałów, tworzy się stanowisko wicedyrektora (art. 97 ust. 1);

- dyrektor szkoły, za zgodą organu prowadzącego szkołę, może tworzyć dodatkowe stanowiska wicedyrektorów lub inne stanowiska kierownicze (art. 97 ust. 2);

- w przedszkolu: 1) liczącym co najmniej 6 oddziałów lub 2) posiadającym oddziały zlokalizowane w różnych miejscach lub 3) w którym co najmniej 2 oddziały pracują dłużej niż 10 godzin dziennie - może być utworzone stanowisko wicedyrektora przedszkola (art. 101 ust. 2).

Wymagania formalne wobec wicedyrektorów określają §§8, 9, 10 i 12 Rozporządzenia Ministra Edukacji Ministra Edukacji Narodowej z 11 sierpnia 2017 r. w sprawie wymagań, jakim powinna odpowiadać osoba zajmująca stanowisko dyrektora oraz inne stanowisko kierownicze w publicznym przedszkolu, publicznej szkole podstawowej, publicznej szkole ponadpodstawowej oraz publicznej placówce. Trzeci powód, dla którego należy mówić tutaj także o wicedyrektorach szkół, to ten, że w wielu sprawach wicedyrektorzy działają z upoważnienia dyrektorów, podpisując między innymi decyzje administracyjne, po czym dokumenty przez nich sygnowane znajdują się w obiegu prawnym i rodzą dla różnych osób i podmiotów określone skutki prawne. Kim więc są osoby, które podejmują się wykonywać czynności związane z kierowaniem szkołą, czy spełniają wszystkie określone prawem wymagania i jaki obraz dyrektora szkoły wyłania się z analizy danych statystycznych.

Między rokiem 2010 a 2017 ogólna liczba szkół (bez przedszkoli i placówek edukacyjnych) w Polsce zmniejszyła się z 35732 do 33 288, to jest o 2444 jednostki, a liczba uczniów z 5571576 do 5185 418, to jest o ponad 386 tys. uczniów i wychowanków. Interesujące jest zatem, czy zmniejszenie liczby szkół i uczniów o 7\% w ciągu czterech lat wpłynęło na liczbę kadry kierowniczej, liczonej liczbą dyrektorów i wicedyrektorów szkół. Z danych MEN wynika, że w końcu września 2010 roku w Polsce było 28600 dyrektorów i 15597 wicedyrektorów, w roku 2014 roku - 27911 dyrektorów szkół i placówek oraz 15568 wicedyrektorów, zaś w roku 2017 - 28437 dyrektorów i 17284 wicedyrektorów (zob. ryc. 1). Tak więc, między rokiem 2010 a 2017 liczba dyrektorów nie zmieniła się, a wicedyrektorów zmniejszyła o 10\%.

Jeśli spojrzeć na tę grupę z uwagi na płeć, daje się zauważyć dominacja (podobnie jak w całym zawodzie nauczycielskim) kobiet. Na interesujących nas stanowiskach kierowniczych w roku 2010 kobiety stanowiły aż 77,7\% (zob. ryc. 1). wszystkich dyrektorów i wicedyrektorów; cztery lata później wartość ta wynosiła już 79\%, a jeszcze trzy lata później wzrosła do $80 \%$ 


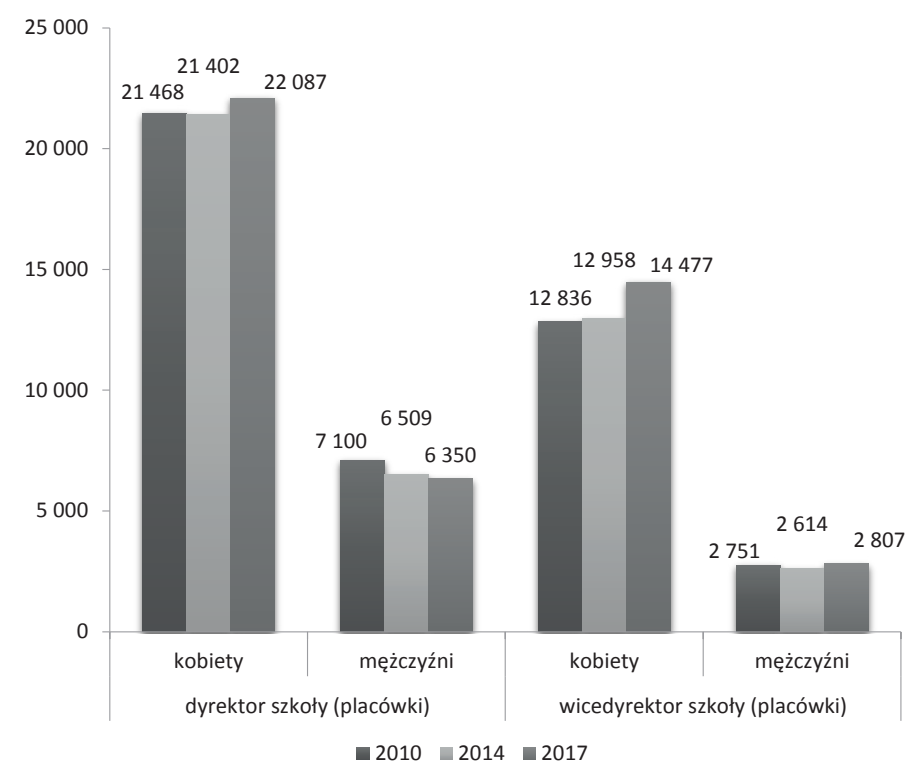

Ryc. 1. Liczba osób zatrudnionych na stanowisku dyrektora i wicedyrektora szkoły, stan na 30 września roku 2010, 2014 i 2017, z podziałem na płeć

(źródło: opracowanie własne na podstawie danych Ministerstwa Edukacji Narodowej z bazy danych Systemu Informacji Oświatowej)

Z kolei w roku 2014 odnotowano 34356 kobiet na stanowisku dyrektora i wicedyrektora w szkole, zaś mężczyzn łącznie na tych stanowiskach było zaledwie 9 123. Rok 2017 liczył 36564 kobiety i 9157 mężczyzn na stanowiskach dyrektorskich w szkołach i placówkach edukacyjnych. Było to widać wyraźnie w grupie dyrektorów oraz wicedyrektorów szkół i placówek edukacyjnych w Polsce. Między rokiem 2010 a 2017 odnotowano prawie 1600 nowych osób na stanowiskach kierowniczych. Co znamienne, kobiet przybyło prawie 2,6 tys., natomiast mężczyzn ubyło blisko 700. Udział kobiet między rokiem 2010 a 2017 wzrósł zatem z 77,7\% do 80,0\%. Tak więc proces feminizacji w zawodzie nauczyciela ${ }^{5}$ ma swoje przełożenie również na stanowiska zarządcze i kierownicze.

W grupie tej dominują, zresztą zgodnie $\mathrm{z}$ obowiązującymi wymogami prawa, nauczyciele z wykształceniem wyższym - magisterskim i licencjackim z przygotowaniem pedagogicznym. Niemniej warto zauważyć, że nieliczna

${ }^{5}$ Feminizacja zawodu nauczycielskiego - jak słusznie zauważa Agnieszka Gromkowska-Melosik, Feminizacja zawodu nauczycielskiego - "różowe kotnierzyki" i paradoksy rynku pracy, Studia Edukacyjne, 2013, 25, s. 86 - nie tyle przyniosła degradację tego zawodu, co „feminizacja była konsekwencją utraty atrakcyjności przez ten zawód", a co za tym idzie zmniejszenia się prestiżu tego zawodu z powodów społeczno-ekonomicznych. 
grupa, bo 122 osoby - 0,28\% (w roku 2014 - 205 osób, 0,47\%) całej populacji legitymowały się wykształceniem niższym od wyznaczonego przez prawo. $\mathrm{Na}$ tym poziomie analizy trudno dociec, czy za każdym razem dotyczyło to osób niebędących nauczycielami - tworzących grupę, jak to się potocznie przyjęło mówić, tak zwanych menedżerów - o których wspomina ustawa, a co zresztą pozostawałoby w sprzeczności ze stawianymi im wysokimi wymaganiami jeśli chodzi o kompetencje w dziedzinie zarządzania.

Tabela 1

Wykształcenie dyrektorów i wicedyrektorów szkół według płci w roku 2017 [osób]

\begin{tabular}{|c|c|c|c|c|c|c|c|c|}
\hline \multirow{3}{*}{$\begin{array}{c}\text { Poziom } \\
\text { wykształcenia }\end{array}$} & \multicolumn{8}{|c|}{ Stanowisko } \\
\hline & \multicolumn{4}{|c|}{ dyrektor szkoły (placówki) } & \multicolumn{4}{|c|}{ wicedyrektor szkoły (placówki) } \\
\hline & kobieta & udział & $\begin{array}{c}\text { mężczy- } \\
\text { zna }\end{array}$ & udział & kobieta & udział & $\begin{array}{l}\text { mężczy- } \\
\text { zna }\end{array}$ & udział \\
\hline $\begin{array}{l}\text { Stopień nauko- } \\
\text { wy doktora lub } \\
\text { doktora habili- } \\
\text { towanego, tytuł } \\
\text { zawodowy magi- } \\
\text { stra z przygoto- } \\
\text { waniem pedago- } \\
\text { gicznym }\end{array}$ & 21417 & $97,0 \%$ & 6187 & $97,4 \%$ & 14171 & $97,9 \%$ & 2748 & $97,9 \%$ \\
\hline $\begin{array}{l}\text { Tytuł zawodowy } \\
\text { magistra bez } \\
\text { przygotowania } \\
\text { pedagogicznego, } \\
\text { tytuł zawodowy } \\
\text { licencjata (inży- } \\
\text { niera) z przygo- } \\
\text { towaniem peda- } \\
\text { gogicznym }\end{array}$ & 554 & $2,5 \%$ & 132 & $2,1 \%$ & 262 & $1,8 \%$ & 49 & $1,7 \%$ \\
\hline $\begin{array}{l}\text { Tytuł zawodo- } \\
\text { wy licencjata } \\
\text { (inżyniera) bez } \\
\text { przygotowania } \\
\text { pedagogicznego, } \\
\text { dyplom ukoń- } \\
\text { czenia kolegium } \\
\text { nauczycielskiego, } \\
\text { nauczycielskiego } \\
\text { kolegium języ- } \\
\text { ków obcych }\end{array}$ & 45 & $0,2 \%$ & 12 & $0,2 \%$ & 18 & $0,1 \%$ & 4 & $0,1 \%$ \\
\hline $\begin{array}{l}\text { Pozostałe kwali- } \\
\text { fikacje }\end{array}$ & 71 & $0,3 \%$ & 19 & $0,3 \%$ & 26 & $0,2 \%$ & 6 & $0,2 \%$ \\
\hline Razem & 22087 & $100,0 \%$ & 6350 & $00,0 \%$ & 4477 & $100,0 \%$ & 2807 & $100,0 \%$ \\
\hline
\end{tabular}

Źródło: opracowanie własne na podstawie danych Ministerstwa Edukacji Narodowej z bazy danych Systemu Informacji Oświatowej. 
Warto zauważyć, że w grupie kadry zarządzającej niewielki udział mają młodzi nauczyciele. Na stanowiskach kierowniczych pracowały zaledwie 423 osoby $(0,9 \%)$ poniżej 30 . roku życia, w tym na stanowisku dyrektora pracowało 230 kobiet, zaś na stanowisku wicedyrektora 160 kobiet, wobec 13 mężczyzn na stanowisku dyrektora i 20 na stanowisku wicedyrektora.

Można postawić tezę, że być może kobiety w okresie rozwijania aktywności zawodowej potrafią bardziej zadbać o swoją karierę. W grupie wiekowej 30-40 lat (12,9\%) było 4843 kobiety (2 660 dyrektorek i 2183 wicedyrektorek), natomiast mężczyzn jedynie 1070 (odpowiednio: 578 i 492 osób). W grupie wiekowej $41-50$ lat $(33,9 \%)$ także przeważały liczbowo kobiety. Łącznie było ich 12628 (odpowiednio: 7083 i 5 545) w stosunku do 2877 mężczyzn (odpowiednio: 1922 i 955). Jednak zdecydowanie największą grupę na stanowiskach kierowniczych w szkole (stanowiskach dyrektora i wicedyrektora) stanowiły osoby po 50. roku życia - 52,2\% (wzrost względem 2014 r. o 5,7\%), w tym kobiety 18703 (odpowiednio 12114 i 6 589) i mężczyźni 5177 (odpowiednio: 3837 i 1340 ). Rozkład wieku polskich dyrektorów i wicedyrektorów ilustruje rycina 2 .

Jednym z wymogów objęcia stanowiska kierowniczego w szkole jest posiadanie przez nauczyciela przystępującego do konkursu na stanowisko dyrektora szkoły stopnia awansu zawodowego nauczyciela mianowanego lub dyplomowanego. Praktyka jednak dowodzi, że ten warunek można ominąć i prawie 3\% (w 2014 roku) wszystkich dyrektorów w Polsce nie miało wymaganego stopnia awansu w czasie konkursu o stanowisko dyrektora. Jeśli dodać do tego dyrektorów i wicedyrektorów bez stopni awansu, to okazuje się, że 4,8\% całej grupy powierzono stanowisko, nie zważając na ów wymóg (w roku 2010 było to 2,6\%, a więc zdecydowanie mniej).

Należy zauważyć, że $\mathrm{w}$ roku 2010 kryterium awansu zawodowego nie spełniało 1014 dyrektorów, natomiast w roku 2017 było to już 2 131, a wśród wicedyrektorów wielkości te wynosiły odpowiednio: 412 i 436 osób. W liczbach bezwzględnych to ponad 2,6 tys. osób, to jest 5,6\% całej grupy. Warto dodać, że w całym systemie edukacji zatrudnionych było 14,8 tys. nauczycieli bez stopnia awansu zawodowego, to jest około 3\% całej populacji ${ }^{6}$.

Zapewne istnieją jakieś racjonalne uzasadnienia takiego stanu, jednakże rodzi się wątpliwość, dlaczego co dwudziesty dyrektor i wicedyrektor nie muszą przejmować się postanowieniami Ustawy i podejmują wyzwania, mając ku temu niewielkie kompetencje, przynajmniej formalne. Zastanawia chociażby fakt, skąd (2017) u ponad stu kobiet i prawie 50 mężczyzn wystarczy podjęcie zatrudnienia w szkole (placówce edukacyjnej), by objąć stanowisko, do którego inni dochodzą latami wytrwałym wysiłkiem skoncentrowanym na rozwoju zawodowym, poszerzając swoją wiedzę i rozwijając umiejętności w toku kształcenia i samokształcenia.

\footnotetext{
${ }^{6}$ Oświata i wychowanie w roku szkolnym 2016/2017, GUS, Warszawa 2017.
} 


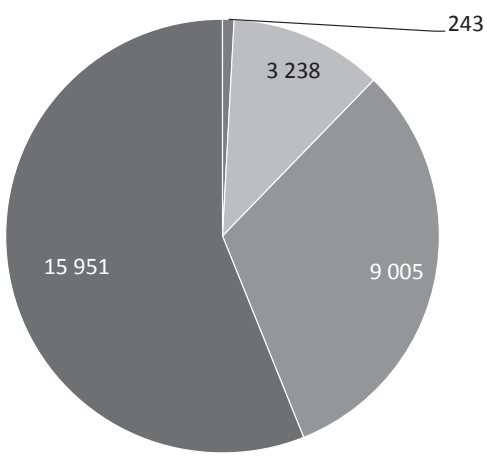

— dyrektorzy pon. 30 r.ż. 1 dyrektorzy 30-40 r.ż.

- dyrektorzy $41-50$ r.że. a dyrektorzy pow. 50 r.ż.

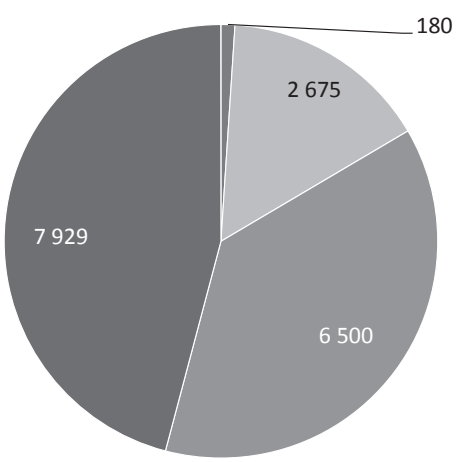

wicedyrektorzy pon. 30 r.ż. wicedyrektorzy 30-40 r.ż.

चicedyrektorzy $41-50$ r.ż. wicedyrektorzy pow. 50 r.ż.

Ryc. 2. Dyrektorzy i wicedyrektorzy szkół według wieku i płci w roku 2017

(źródło: opracowanie własne na podstawie danych Ministerstwa Edukacji Narodowej $\mathrm{z}$ bazy da-nych Systemu Informacji Oświatowej)

Tabela 2

Liczba dyrektorów i wicedyrektorów według stopni awansu 30 września w latach 2010 i 2017 [osób]

\begin{tabular}{|l|c|c|c|c|c|c|c|c|}
\hline & \multicolumn{7}{|c|}{ Stanowisko } \\
\hline \multirow{2}{*}{$\begin{array}{l}\text { Stopień awansu } \\
\text { zawodowego }\end{array}$} & \multicolumn{2}{|c|}{ dyrektor szkoły (placówki) } & \multicolumn{2}{c|}{ wicedyrektor szkoły (placówki) } \\
\cline { 2 - 9 } & kobieta & \multicolumn{2}{|c|}{ mężczyzna } & \multicolumn{2}{c|}{ kobieta } & \multicolumn{2}{c|}{ mężczyzna } \\
\hline $\begin{array}{l}\text { Rauczyciel bez } \\
\text { stopnia awansu } \\
\text { zawodowego } \\
\text { zatrudniony } \\
\text { na podstawie } \\
\text { art. 10 ust.9 }\end{array}$ & 2010 & 2017 & 2010 & 2017 & 2010 & 2017 & 2010 & 2017 \\
$\begin{array}{l}\text { Karty Nauczy- } \\
\text { ciela }\end{array}$ & - & 22 & - & 7 & - & 2 & - & 0 \\
\hline $\begin{array}{l}\text { Osoba bez } \\
\text { stopnia awansu } \\
\text { zawodowego } \\
\text { zatrudniona } \\
\text { na podstawie } \\
\text { art. 15 ust. 1-6 } \\
\begin{array}{l}\text { Ustawy Prawo } \\
\text { oświatowe }\end{array}\end{array}$ & - & 77 & - & 23 & - & 16 & - & 2 \\
\hline $\begin{array}{l}\text { Nauczyciel bez } \\
\text { stopnia awansu } \\
\text { zawodowego }\end{array}$ & 389 & 1108 & 211 & 294 & 72 & 235 & 41 & 68 \\
\hline
\end{tabular}




\begin{tabular}{|l|c|c|c|c|c|c|c|c|}
\hline Stażysta & 35 & 99 & 11 & 28 & 16 & 53 & 4 & 17 \\
\hline Kontraktowy & 288 & 1029 & 80 & 123 & 211 & 625 & 68 & 109 \\
\hline Mianowany & 3807 & 2942 & 1257 & 881 & 1909 & 1733 & 542 & 371 \\
\hline Dyplomowany & 16969 & 16810 & 5553 & 4994 & 10633 & 11813 & 2101 & 2240 \\
\hline Razem & $\mathbf{2 1 4 8 8}$ & $\mathbf{2 2 ~ 0 8 7}$ & $\mathbf{7 1 1 2}$ & $\mathbf{6 3 5 0}$ & $\mathbf{1 2 ~ 8 4 1}$ & $\mathbf{1 4} \mathbf{4 7 7}$ & $\mathbf{2 7 5 6}$ & $\mathbf{2 8 0 7}$ \\
\hline
\end{tabular}

Źródło: opracowanie własne na podstawie danych Ministerstwa Edukacji Narodowej z bazy danych Systemu Informacji Oświatowej.

Pewnym dopełnieniem informacji o stopniach awansu zawodowego nauczycieli jest informacja, jak owe stopnie w ogóle funkcjonują w systemie.

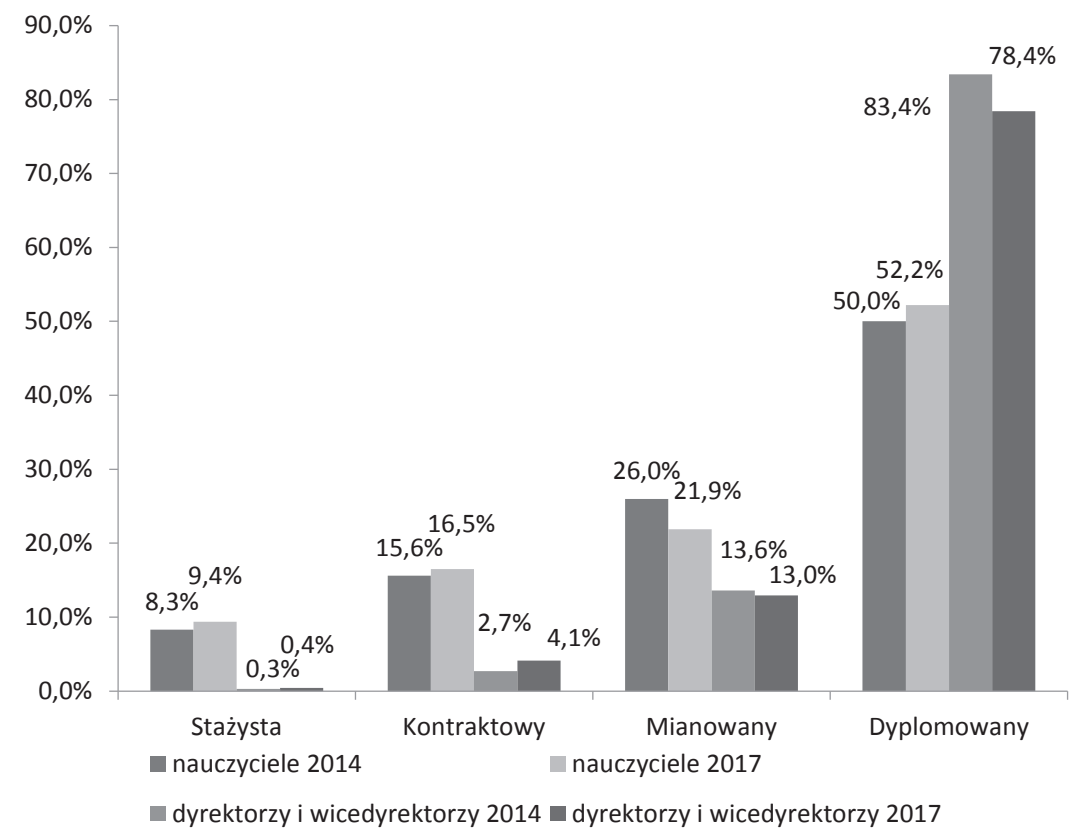

Ryc. 3. Udział nauczycieli i dyrektorów, łącznie z wicedyrektorami, według stopni awansu zawodowego w ogólnej liczbie nauczycieli i kadry kierowniczej oświaty, stan na 30 września 2014 i 2017 roku (\%)

(źródło: opracowanie własne na podstawie danych Ministerstwa Edukacji Narodowej z bazy danych Systemu Informacji Oświatowej)

Proporcje udziału poszczególnych stopni w grupie nauczycieli i kadry kierowniczej są zróżnicowane. W przypadku nauczycieli stażystów i kontraktowych występuje nawet, nie uwzględniana przez prawo, wspomniana 
wyżej nadreprezentacja, gdyż nauczyciele legitymujący się tymi stopniami w zasadzie nie powinni być dopuszczeni do zajmowania stanowisk dyrektorów i wicedyrektorów. Natomiast grupa nauczycieli mianowanych jest reprezentowana proporcjonalnie dwa razy rzadziej, niż wskazywałby na to ich udział w całej populacji, a jednocześnie nauczyciele dyplomowani zajmują o 50\% częściej stanowiska kierownicze, niż wskazywałby na to ich udział w populacji.

Pytanie, jakie rodzi się na tym etapie analizy jest pytaniem o motywacje. Można je sformułować następująco: „Dlaczego stanowiska kierownicze powierzane są częściej nauczycielom z wyższym stopniem awansu zawodowego?" Jednocześnie pojawia się kolejne pytanie, dlaczego organy do tego powołane, odstępując od uwarunkowań wynikających z prawa, powołują osoby nie spełniające warunku posiadania odpowiedniego stopnia awansu zawodowego oraz w jakim zakresie kwestia ta dotyczy dyrektorów zatrudnionych na podstawie b. art. 36 ust. 2 USO lub obowiązującego dziś art. 62 ust. 2 UPO, co mogłoby w pewnym stopniu uzasadniać tego typu działania.

Tabela 3

Liczba dyrektorów i wicedyrektorów według stażu pedagogicznego w roku szkolnym 2017/18, stan na 30 września 2017 (osób)

\begin{tabular}{|c|c|c|c|c|c|c|c|c|}
\hline \multirow{4}{*}{$\begin{array}{l}\text { Staż peda- } \\
\text { gogiczny } \\
\text { dyrekto- } \\
\text { rów i wi- } \\
\text { cedyrekto- } \\
\text { rów }\end{array}$} & \multicolumn{8}{|c|}{ Stanowisko } \\
\hline & \multicolumn{4}{|c|}{ dyrektor szkoły (placówki) } & \multicolumn{4}{|c|}{ wicedyrektor szkoły (placówki) } \\
\hline & \multicolumn{2}{|c|}{ kobieta } & \multicolumn{2}{|c|}{ mężczyzna } & \multicolumn{2}{|c|}{ kobieta } & \multicolumn{2}{|c|}{ mężczyzna } \\
\hline & $\begin{array}{l}\text { liczba } \\
\text { (osób) }\end{array}$ & $\begin{array}{c}\text { udział } \\
(\%)\end{array}$ & $\begin{array}{l}\text { liczba } \\
\text { (osób) }\end{array}$ & $\begin{array}{c}\text { udział } \\
(\%)\end{array}$ & $\begin{array}{l}\text { liczba } \\
\text { (osób) }\end{array}$ & $\begin{array}{c}\text { udział } \\
(\%)\end{array}$ & $\begin{array}{l}\text { liczba } \\
\text { (osób) }\end{array}$ & $\begin{array}{c}\text { udział } \\
(\%)\end{array}$ \\
\hline $\begin{array}{l}\text { poniżej } \\
10 \text { lat }\end{array}$ & 1721 & $7,8 \%$ & 333 & $5,2 \%$ & 1080 & $7,5 \%$ & 242 & $8,6 \%$ \\
\hline 10-20 lat & 4062 & $18,4 \%$ & 1354 & $21,3 \%$ & 3735 & $25,8 \%$ & 843 & $30,0 \%$ \\
\hline 21-30 lat & 7855 & $35,6 \%$ & 2513 & $39,6 \%$ & 5589 & $38,6 \%$ & 1135 & $40,4 \%$ \\
\hline 31-40 lat & 8069 & $36,5 \%$ & 1972 & $31,1 \%$ & 3927 & $27,1 \%$ & 553 & $19,7 \%$ \\
\hline $\begin{array}{l}\text { powyżej } \\
40 \text { lat }\end{array}$ & 380 & $1,7 \%$ & 178 & $2,8 \%$ & 146 & $1,0 \%$ & 34 & $1,2 \%$ \\
\hline Razem & 22087 & $100,0 \%$ & 6350 & $100,0 \%$ & 14477 & $100,0 \%$ & 2807 & $100,0 \%$ \\
\hline
\end{tabular}

Źródło: opracowanie własne na podstawie danych Ministerstwa Edukacji Narodowej z bazy danych Systemu Informacji Oświatowej.

Kolejna odsłona nie ilustruje spełniania wymogów formalnych, a jedynie jest fotografią konkretnej sytuacji. Sumaryczne zestawienie dla obu podgrup (dyrektorów i wicedyrektorów) prezentuje prawie dokładny rozkład naturalny. 


\section{Pozycja i zadania dyrektora szkoły}

W myśl polskiego prawa, dyrektor szkoły jest postacią kluczową i szczególnie docenianą z punktu widzenia miejsca, jakie jest mu w niej przypisane i roli, jaką ma odgrywać. Dyrektor szkoły powinien przejawiać wysokie poczucie odpowiedzialności za szkołę i kształtowanie korzystnych warunków kształcenia, wychodzić naprzeciw potrzebom edukacyjnym uczniów, współpracować na rzecz innych, podejmować strategiczne decyzje odnośnie kierunku rozwoju szkoły, mądrze wspierać pracę i rozwój zawodowy nauczycieli, rozumieć szkołę jako społeczność uczących się oraz wykorzystywać wszystkie dostępne środki na rzecz podniesienia jakości pracy i rangi szkoły ${ }^{7}$.

Ustawa z 14 grudnia 2016 roku Prawo oświatowe ${ }^{8}$ i rozporządzenia wykonawcze $^{9}$ do niej wyraźnie wzmacniają pozycję dyrektora szkoły i jego uprawnienia, ograniczając jednocześnie kompetencje władcze rady pedagogicznej. Ten kierunek stawiania na jednoosobowe kierownictwo w oświacie - w związku z wdrażanymi właśnie zmianami - jest dość charakterystyczny. Wydaje się, że winni być jego świadomi nie tylko potencjalni kandydaci na to stanowisko, ale także dyrektorzy obecnie wykonujący swoje zadania. Wszak należy pamiętać, że wzmacnianie pozycji dyrektora pociąga za sobą, jakże oczywisty, wzrost jego odpowiedzialności.

W ustawach, ale także całym ogromnym zbiorze prawa, znajdują się porozrzucane najprzeróżniejsze zadania, jakie powinien wykonywać dyrektor szkoły. Jednakże, podjęcie próby określenia, co kryje się za terminem dyrektor szkoły, wyłącznie poprzez kompetencje w jakie jest wyposażony, zadania jakie ma realizować i uprawnienia z których może korzystać, jest przedsięwzięciem trudnym, nie zawsze prowadzącym do skondensowanej, jasnej, precyzyjnej i mającej zastosowanie w każdych warunkach definicji. Z pewnością, podstawowym zadaniem dyrektora szkoły jest szeroko rozumiane kierowanie szkołą. Dyrektor jest

jej przedstawicielem na zewnątrz, przełożonym służbowym wszystkich pracowników szkoły, przewodniczącym rady pedagogicznej. Dyrektor sprawuje opiekę nad dziećmi i młodzieżą uczącą się w szkole ${ }^{10}$.

${ }^{7}$ J. Madalińska-Michalak, Skuteczne przywództwo w szkołach na obszarach zaniedbanych społecznie. Studium porównawcze, Łódź 2012.

${ }^{8}$ DzU z 2017, poz. 59 ze zm.

9 Zob.: Rozporządzenie Ministra Edukacji Narodowej z 17 marca 2017 r. w sprawie szczegółowej organizacji publicznych szkół i publicznych przedszkoli (DzU z 2017 r. poz. 649).

${ }^{10} \mathrm{KN}$, art. 7 ust. 1. (DzU z 2017 r. poz. 1189). 
W Ustawie z 7 września 1991 r. o systemie oświaty (USO, 1991) ${ }^{11}$ związek frazeologiczny dyrektor szkoły przywoływany jest w różnych formach fleksyjnych 159 razy, wypierając tym samym zagadnienia związane usytuowaniem dyrektora szkoły w Karcie Nauczyciela. W Ustawie Prawo oświatowe (UPO, 2016) podobna analiza daje 189 trafień. Jeśli zauważyć, że w 2009 roku przywołań tych było około 9012, to wzrosty przekładają się na bezpośrednio nałożone ustawą na dyrektora zadania oraz ustalone kompetencje i uprawnienia. Należy także dodać inne przepisy tak zwanego prawa oświatowego, które nakładają na dyrektora szkoły setki innych, często bardzo drobiazgowych zadań. Sześć lat temu doliczono się ponad 1100 zadań będących prawem, a więc obłożonych klauzulą obowiązkowej realizacji, które nałożono na dyrektorów ${ }^{13}$. Ponad 400 z nich były to zadania wspólne dla dyrektorów wszystkich typów szkół i placówek. Ale dyrektor realizował i realizuje także zadania z zakresu prawa nieletnich, finansów publicznych, prawa administracyjnego, cywilnego, prawa pracy i tym podobne. Podstawą tamtego opracowania było 110 aktów prawnych, wydanych przez ponad 15 podmiotów państwa, które nakładały bezpośrednio na dyrektorów szkół jakiekolwiek zadania. Warto podkreślić, że opracowanie nie obejmowało setek zadań wynikających ze wspomnianych wyżej przepisów zamieszczonych w innych obszarach prawa, choćby administracyjnego, finansów publicznych, rodzinnego, gospodarczego, budowlanego, sanitarnego i tym podobnych.

Skumulowane w przywołanym opracowaniu zadania podzielono na dwie grupy: zadania w zakresie przygotowania, realizowania i rozliczania zadań edukacyjnych oraz zadania dyrektorów szkół w zakresie zatrudniania i zwalniania nauczycieli. Następnie przypisano je jako powszechne dyrektorom wszystkich szkół i placówek oraz szczególne dyrektorom czterdziestu pięciu typów szkół i placówek edukacyjnych. Tak wyłonione zadania otrzymały swój wyraz w haśle i rozwijającym je omówieniu, z jednoczesnym odesłaniem do konkretnego aktu prawnego, ujętego w ponumerowanym wykazie, a w nim do konkretnego przepisu. Przykład:

Zawiadamianie kuratora oświaty i organu prowadzącego szkołę o powołaniu komisji dla ustalenia zakresu zniszczeń oraz od-

[45] $\S 21$ ust. 4

Źródło: Antoni Jeżowski, Zadania dyrektora szkoły i placówki oświatowej, Wrocław 2009, s. 35.

\footnotetext{
11 W stanie prawnym obowiązującym 6 lipca 2015 roku.

12 A. Jeżowski, Zadania dyrektora szkoły i placówki oświatowej, Wrocław 2009, s. 17.

13 Tamże, s. 18.
} 
To bardziej szczegółowe przywołanie w tym miejscu tamtego opracowania ma jedynie wskazać, że pewne prace analityczne i badawcze zostały już wykonane, a jakie ma to przełożenie na współczesną szkolną rzeczywistość spróbuję pokazać w innym miejscu.

Na potrzeby niniejszego opracowania dokonano przeglądu sześciu obowiązujących 1 września 2018 roku ustaw z obszaru spraw edukacyjnych: Ustawa z 14 grudnia 2016 r. Prawo oświatowe (163 kompetencje, uprawnienia i zadania), Ustawa przepisy wprowadzające ustawę z 14 grudnia $2016 \mathrm{r}$. Prawo oświatowe (14), Ustawa z 7 września 1991 r. o systemie oświaty (73), Ustawa z 27 października 2017 r. o finansowaniu zadań oświatowych (17), Ustawa z 26 stycznia 1982 r. Karta Nauczyciela (125) oraz Ustawa z 15 kwietnia 2011 r. o systemie informacji oświatowej (12). W sumie wyodrębniono 404 kompetencje, uprawnienia i zadania wynikające wprost $\mathrm{z}$ ustaw nie pretendujących do roli wykazu wyczerpującego, gdyż pominięto ciągle ewoluujące rozporządzenia wykonawcze.

Treść Rozporządzenia Ministra Edukacji Narodowej z 25 sierpnia 2017 r. w sprawie nadzoru pedagogicznego

Systematyzując te rozważania, należy wyraźnie stwierdzić, że dyrektor realizuje setki różnych zadań, z których wiele jest zadaniami budżetowymi, gdyż finansowane są bezpośrednio $\mathrm{z}$ budżetu (jednostki samorządu terytorialnego lub państwa). O jeszcze jednej grupie zadań musimy w tym miejscu wspomnieć - są to zadania statutowe szkoły. Statut szkoły lub placówki zawiera więc w szczególności: nazwę i typ szkoły oraz jej siedzibę, a w sytuacji kiedy szkoła wchodzi w skład zespołu szkół - także nazwę tego zespołu, imię szkoły, o ile zostało nadane, nazwę i siedzibę organu prowadzącego szkołę oraz cele i zadania szkoły wynikające z przepisów prawa oraz sposób ich wykonywania, $\mathrm{w}$ tym $\mathrm{w}$ zakresie udzielania pomocy psychologiczno-pedagogicznej, organizowania opieki nad dziećmi niepełnosprawnymi, umożliwiania uczniom podtrzymywania poczucia tożsamości narodowej, etnicznej, językowej i religijnej, z uwzględnieniem zasad bezpieczeństwa oraz zasad promocji i ochrony zdro$w_{i a}{ }^{14}$. Tę grupę zadań, w połączeniu $z$ celami szkoły, definiuje sama społeczność szkolna, redagując, uchwalając, a później realizując statut szkoły.

Zadania dyrektora szkoły wynikają więc z kilkuset aktów normatywnych. Ich analiza pokazuje, że obok zadań ściśle związanych z podejmowaniem decyzji administracyjnych (aktów stosowania prawa administracyjnego i rozstrzygnięć władczych zawierających normy prawa administracyjnego i podlegających trybowi odwoławczemu oraz zaskarżaniu) czy decyzji finansowych, podejmuje on wiele decyzji o charakterze prakseologicznym, które

\footnotetext{
${ }^{14}$ UPO, 2016, art. 98 ust 1 pkt 1-4.
} 
nie są rozstrzygnięciami władczymi i nie zawierają norm prawa administracyjnego. Decyzje o charakterze prakseologicznym wynikają w dużej mierze z realizacji zadań, w których ujawnia się przydatność zarządzania prowadzącego do usprawniania pracy administracyjnej szkoły i przywództwa pozwalającego usprawnić proces zarządzania szkołą.

Treść Rozporządzenia Ministra Edukacji Narodowej z 25 sierpnia 2017 r. w sprawie nadzoru pedagogicznego ${ }^{15}$ dobitnie pokazuje, że dyrektor szkoły jest odpowiedzialny nie tylko za administrowanie szkołą, ale pełni funkcje na wskroś pedagogiczne, sprzyjające rozwojowi nauczycieli, uczniów i rodziców oraz środowiska szkoły. Dyrektor szkoły lub placówki we współpracy z innymi nauczycielami zajmującymi stanowiska kierownicze, $\mathrm{w}$ ramach sprawowanego nadzoru pedagogicznego, przeprowadza ewaluację wewnętrzną i wykorzystuje jej wyniki do doskonalenia jakości pracy szkoły lub placówki, kontroluje przestrzeganie przez nauczycieli przepisów prawa dotyczących działalności dydaktycznej, wychowawczej i opiekuńczej oraz innej działalności statutowej szkoły lub placówki, wspomaga nauczycieli w realizacji ich zadań, w szczególności przez diagnozę pracy szkoły lub placówki, planowanie działań rozwojowych, w tym motywowanie nauczycieli do doskonalenia zawodowego, prowadzenie działań rozwojowych, $w$ tym organizowanie szkoleń i narad orz monitoruje pracę szkoły lub placówki.

W celu realizacji tych zadań dyrektor, we współpracy z nauczycielami, w szczególności analizuje dokumentację przebiegu nauczania i obserwuje prowadzone przez nauczycieli zajęcia dydaktyczne, wychowawcze i opiekuńcze oraz inne zajęcia i czynności wynikające z działalności statutowej szkoły lub placówki ${ }^{16}$. Jednocześnie dyrektor szkoły lub placówki opracowuje na każdy rok szkolny plan nadzoru pedagogicznego, który przedstawia na zebraniu rady pedagogicznej w terminie do 15 września roku szkolnego, którego ten plan dotyczy ${ }^{17}$, a w terminie do 31 sierpnia przedstawia na zebraniu rady pedagogicznej wyniki i wnioski ze sprawowanego nadzoru pedagogicznego ${ }^{18}$.

Zadania realizowane przez dyrektora szkoły wywodzą się z różnych źródeł, dotyczą najróżniejszej materii i koncentrują jego działania na wachlarzu zagadnień tak rozległych, że chyba tylko dzięki sporemu wyczuciu problemów, doświadczeniu i wiedzy nie gubi się w ich gąszczu i ogarnia je swoim kierownictwem. Dyrektor szkoły wszystkie swoje zadania musi wykonywać z jednakową powagą i odpowiedzialnością, bo dopiero suma tych działań może zapewnić sukces kierowanej przez niego szkole i, w konsekwencji, jemu samemu.

${ }^{15}$ Rozporządzenie Ministra Edukacji Narodowej z 25 sierpnia 2017 r. w sprawie nadzoru pedagogicznego (DzU z 2017 r. poz. 1658).

16 Tamże, § 22.

17 Tamże, § 24.

18 Tamże, § 25. 


\section{Podsumowanie i konkluzje}

W złożonym kontekście debat nad edukacją w naszym kraju oraz warunkami pracy i sytuacją nauczycieli, jak i dyrektorów, nad rozwiązaniami systemowymi i programowymi bez wątpienia ważną rolą odgrywa nie tylko nauczyciel $^{19}$, ale w zasadniczej mierze dyrektor szkoły, któremu przypisuje się rolę strategiczną $\mathrm{w}$ rozwoju szkoły i efektywności systemu edukacji. Istnieją dowody na to, że dobrzy dyrektorzy szkół stoją w centrum reform edukacyjnych w szkołach i że bez ich przywództwa wysiłki podejmowane na rzecz podnoszenia osiągnięć edukacyjnych uczniów nie przynoszą oczekiwanych rezultatów ${ }^{20}$. Refleksja nad rozwojem szkoły i jakością jej pracy nie omija zatem problematyki kierowania szkołą, a wraz z tym pracy dyrektora szkoły oraz wyzwań i zadań, z jakimi się zmierza.

Współcześnie trudno mówić o naturze pracy kierowniczej dyrektora szkoły, o specyfice przypisywanych do jego stanowiska zadań, jeśli nie przybliżymy sobie postaci, jaką jest dyrektor szkoły. Odpowiedzi na postawione w tym artykule pytania pozwoliły na nakreślenie obrazu dyrektora szkoły w Polsce. Przedstawione tutaj wyniki prowadzonych analiz pozwalają mieć lepsze wyobrażenie o tym, kto może ubiegać się o stanowisko dyrektora szkoły w Polsce, kim są dyrektorzy szkół i jakie stoją przed nimi zadania, które de facto wyznaczają pole ich odpowiedzialności zawodowej. Skłaniają one także do dalszych przemyśleń.

Praca na stanowisku dyrektora szkoły wiąże się z olbrzymią odpowiedzialnością, stąd nie jest ono sprowadzane do przeciętnego miejsca, z jakiego się ją świadczy. Co prawda, do zajmowania tego stanowiska trzeba z reguły wykonywać zawód nauczyciela, to jednak w kontekście tego co już wcześniej powiedziano, $\mathrm{w}$ Polsce $\mathrm{w}$ rozumieniu przepisów ogólnych i ustrojowych edukacji nie ma zawodu dyrektora szkoły w rozumieniu: „z zawodu jestem dyrektorem szkoły". Zajmowanie stanowiska dyrektora szkoły jest z reguły nadbudowane na wyuczonym i wykonywanym zawodzie podstawowym, jakim jest zawód nauczyciela, choć - i warto to szczególnie podkreślić - Minister Pracy i Polityki Społecznej umieścił zawód dyrektora szkoły w swoim Rozporządzeniu z 27 kwietnia 2010 r. w sprawie klasyfikacji zawodów i specjalności na potrzeby rynku pracy oraz jej stosowania ${ }^{21}$. Warto zatem zasta-

${ }^{19}$ Szerzej na ten temat piszę w artykule: J. Madalińska-Michalak, Filary pracy a kompetencje nauczyciela, [w:] Edukacja i praca nauczyciela; ciagtość - zmiana - konteksty, red. J. Madalińska-Michalak, N.G. Pikuła, K. Białożyt, Kraków 2017, s. 29-56.

${ }^{20}$ Zob. J. Madalińska-Michalak, Skuteczne przywództwo w szkołach na obszarach zaniedbanych społecznie. Studium porównawcze, Łódź 2012.

${ }^{21}$ Zawód ten umieszczony jest w charakterystycznym ujęciu ministerialnej systematyki, $\mathrm{w}$ grupie 1. - przedstawiciele władz publicznych, wyżsi urzędnicy i kierownicy - grupa ta obejmuje zawody, w których podstawowymi zadaniami są: planowanie, określanie i realizo- 
nowić się, biorąc pod uwagę różne okoliczności, czy praca dyrektora szkoły jest związana jedynie z zajmowanym przez dyrektora stanowiskiem w strukturze organizacyjnej szkoły, czy też podstawą jej świadczenia jest wykonywanie zawodu dyrektora szkoły. Poruszany dylemat, czy dyrektor szkoły to zawód czy jedynie stanowisko powierzane na określony czas nauczycielowi konkretnego przedmiotu, trudno w tym miejscu rozstrzygnąć. Niemniej jednak, badania nad dyrektorami szkół w Polsce pokazują, że kwestią domagającą się szczególnego namysłu jest profesjonalizacja działań dyrektora szkoły i podjęcie odpowiedzi na pytanie, „czy nie powinniśmy tworzyć warunków ku temu, by móc wreszcie faktycznie mówić o zawodzie dyrektora szkoły w naszym kraju, co jest tak często zaniedbywane w dyskusjach nad szkołą i pracą dyrektorów szkół"22.

Rozważania w tym zakresie kierują z kolei naszą uwagę w stronę kolejnej kwestii, jaką jest rola i status dyrektora szkoły w Polsce ${ }^{23}$. Stanowisko dyrektora szkoły lub placówki edukacyjnej w Polsce jest wielowymiarowe. Przy jego biurku, można powiedzieć, niejako spotykają się czynniki organizacyjne, prawne, społeczne, pedagogiczne, etyczne, ekonomiczne, ideologiczne i pewnie jeszcze dziesiątki innych. Oczekiwania stawiane przed nim wykraczają poza standardowe granice stawiane $w$ większości krajów świata, ale też wynikająca $\mathrm{z}$ tego samoświadomość i odpowiedzialność sytuuje go w nieco innym wymiarze.

Biorąc pod uwagę rolę dyrektora szkoły wyznaczoną przepisami prawa, można sądzić, że stwarzają one szeroką autonomię do jego działań i że jego pozycja uległa ostatnio wyraźnemu wzmocnieniu. Niemniej jednak, niektóre środowiska od dłuższego już czasu wyrażają opinię, że dyrektorzy szkół są najsłabszym ogniwem w systemie edukacji ${ }^{24}$. Problem w zasadniczej mierze dotyczy rozbieżności między formalnym zakresem uprawnień dyrektorów

wanie podstawowych celów i kierunków polityki państwa, formułowanie przepisów prawnych oraz kierowanie działalnością jednostek administracji publicznej, a także sprawowanie funkcji zarządzania w przedsiębiorstwach lub ich wewnętrznych jednostkach organizacyjnych, w podgrupie 13. - kierownicy do spraw produkcji i usług, i dalej: 134. - kierownicy/dyrektorzy w instytucjach usług wyspecjalizowanych, a następnie 1345. - kierownicy w instytucjach edukacyjnych i ostatecznie 134501. - dyrektor szkoły. Przytoczona systematyka oparta jest na logicznych przesłankach, sytuujących dyrektora szkoły wśród różnych wyspecjalizowanych kierowników. Można się chyba pokusić o stwierdzenie, że dyrektor szkoły, w tym ujęciu, jest jednym z zawodów kierowniczych. Zob. Rozporządzenie Ministra Pracy i Polityki Społecznej z 27 kwietnia 2010 r. w sprawie klasyfikacji zawodów i specjalności na potrzeby rynku pracy oraz jej stosowania.

${ }_{22}$ J. Madalińska-Michalak, Dyrektor szkoty liderem - inspiracje i perspektywy, Warszawa 2015, s. 378 .

${ }^{23}$ A. Pery, Status dyrektora szkoły. Poradnik dla samorządów i dyrektorów szkót, Warszawa 2012; S. Więsław, Sytuacja i status zawodowy dyrektorów.

${ }^{24} \mathrm{~S}$. Więsław, Sytuacja i status zawodowy dyrektorów. 
szkół i realnej możliwości skorzystania z tych uprawnień. Badania pokazują, że w dwóch najważniejszych obszarach kierowania szkołą - obszarze polityki personalnej oraz obszarze decydowania o finansach szkoły - dyrektorzy czują się ograniczeni w swoich działaniach. Brak selekcji do zawodu nauczyciela, masowość kształcenia na studiach pedagogicznych oraz biurokratyczny awans zawodowy uniemożliwiają dyrektorom szkół prowadzenie odpowiedniej polityki kadrowej.

\section{BIBLIOGRAFIA}

Gromkowska-Melosik A., Feminizacja zawodu nauczycielskiego - "różowe kotnierzyki" i paradoksy rynku pracy, Studia Edukacyjne, 2013, 25.

Jeżowski A., Zadania dyrektora szkoły i placówki oświatowej, Instytut Badań w Oświacie, Wrocław 2009.

Jeżowski A.J., Madalińska-Michalak J., Dyrektor szkoły - koncepcje i wyzwania. Między teoria a praktyką. Ośrodek Rozwoju Edukacji, Warszawa 2015.

Madalińska-Michalak J., Skuteczne przywództwo w szkołach na obszarach zaniedbanych społecznie. Studium porównawcze, Wydawnictwo Uniwersytetu Łódzkiego, Łódź 2012.

Madalińska-Michalak J., Dyrektor szkoty liderem - inspiracje i perspektywy, Wolters Kluwer, Warszawa 2015.

Madalińska-Michalak J., Filary pracy a kompetencje nauczyciela, [w:] Edukacja i praca nauczyciela; ciąłość - zmiana - konteksty, red. J. Madalińska-Michalak, N.G. Pikuła, K. Białożyt, Wydawnictwo Scriptum, Kraków 2017.

Oświata i wychowanie w roku szkolnym 2016/2017, GUS, Warszawa 2017.

Pery A., Status dyrektora szkoły. Poradnik dla samorząów i dyrektorów szkót, Ośrodek Rozwoju Edukacji, Warszawa 2012.

Rozporządzenie Ministra Edukacji Narodowej z 17 marca 2017 r. w sprawie szczegółowej organizacji publicznych szkół i publicznych przedszkoli (DzU z 2017 r., poz. 649).

Rozporządzenie Ministra Edukacji Narodowej z 25 sierpnia 2017 r. w sprawie nadzoru pedagogicznego (DzU z 2017 r. poz. 1658).

Rozporządzenie Ministra Pracy i Polityki Społecznej z 27 kwietnia 2010 r. w sprawie klasyfikacji zawodów i specjalności na potrzeby rynku pracy oraz jej stosowania (DzU z 2010 r., nr 82, poz. 537).

Ustawa z 14 grudnia 2016 r. - Przepisy wprowadzające ustawę - Prawo oświatowe (DzU z 2017 r. poz. 60 ze zm.).

Więsław S., Sytuacja i status zawodowy dyrektorów szkót i placówek oświatowych, Ośrodek Rozwoju Edukacji, Warszawa 2012. 